\title{
MATRIKS INTERNAL FACTOR EVALUATION (IFE) DAN EXTERNAL FACTOR EVALUATION (EFE) BUAH NAGA ORGANIK (Hylocereus Undatus)
}

\author{
Kustiawati Ningsih *), Hamamah *) \\ ${ }^{*}$ Program Studi Agribisnis, Fakultas Pertanian, Universitas Islam Madura, \\ ningsihkustiawati@yahoo.com
}

\begin{abstract}
ABSTRAK
Penelitian ini bertujuan untuk menganalisis faktor-faktor internal dan eksternal usahatani buah naga organik. Penelitian ini dilakukan pada usahatani buah naga organik di Desa Blumbungan, Kecamatan Larangan, Kabupaten Pamekasan. Pemilihan lokasi tersebut dilakukan secara sengaja (purposive) dengan pertimbangan bahwa Desa Blumbungan merupakan daerah pengembangan buah naga organik di Kabupaten Pamekasan. Penelitian dilakukan Bulan Juni sampai Agustus 2013. Hasil analisis menunjukkan bahwa berdasarkan matriks IFE kekuatan utama usahatani buah naga organik adalah sudah memiliki pasar tetap, dengan skor sebesar 0,342. Sedangkan kelemahan utama usahatani buah naga yaitu belum diterapkannya SIM dalam sistem manajerial dengan skor sebesar 0,045. Berdasarkan hasil perhitungan matriks EFE, Peluang utama usahatani buah naga adalah kebijakan pemerintah mengenai "Go Organic 2010" dan dukungan untuk mengembangkan usahatani, dengan skor sebesar 0,252. Sedangkan ancaman utama usahatani buah naga yaitu jaringan distribusi dan pemasaran pesaing sudah lebih luas, dengan skor sebesar 0,250.
\end{abstract}

\section{ABSTRACT}

This study aims to analyze the factors internal and external organic dragon fruit farm. The research was conducted on organic dragon fruit farm in the Blumbungan Village, Larangan District, Pamekasan. Site selection is done purposive with the consideration that the Blumbungan village is an area organic dragon fruit development in Pamekasa. The study was conducted in June through August 2013. The analysis showed that the main strength of the IFE matrix based farming organic dragon fruit is already having fixed market, with a score of 0.342 . While the main weakness that is not a dragon fruit farm implementation of SIM in the managerial system with a score of 0.045 . Based on calculations EFE matrix , the main Opportunity dragon fruit farm is government policy regarding the " Go Organic 2010" and support to develop the farm, with a score of 0.252 . While the primary threat a dragon fruit farm and a distribution network that is already more extensive marketing competitors, with a score of 0.250 .

\section{PENDAHULUAN}

$\begin{array}{rccr}\text { Bagi } & \text { negara } & \text { yang } & \text { sedang } \\ \text { berkembang } & \text { sektor } & \text { petanian } & \text { masih }\end{array}$ merupakan sektor primadona, begitu pula di Indonesia. Hal ini di karenakan sektor pertanian masih merupakan penyedia lapangan pekerjaan yang terbesar dalam menyerap tenaga kerja (Soekartawi, 1989).
Pengembangan komoditas hortikultura, khususnya buah-buahan dapat dirancang sebagai salah satu sumber pertumbuhan baru dalam perekonomian nasional. Perkembangan agribisnis buahbuahan akan memberi nilai tambah bagi produsen (petani) dan industri pengguna serta dapat memperbaiki keseimbangan gizi bagi konsumen. Potensi pengembangan tanaman buah-buahan di Indonesia 
didukung oleh banyak faktor (Rukmana, 2003).

Selain sebagai buah segar, buah naga pun dapat digunakan sebagai bahan pewarna dan olahan es krim. Oleh karena itu, tidak tertutup kemungkinan buah naga ini dikembangkan menjadi buah yang memasyarakat. Pada pertengahan tahun 2000, di beberapa swalayan Jakarta pernah dibanjiri buah naga yang diimpor dari Thailand. Saat itu, promosi dilakukan besar-besaran. Kehadirannya pun mengejutkan karena buah ini dipromosikan sebagai buah yang rasanya lebih manis dari semangka walaupun agak asam. Trend buah naga bukan saja hanya dimiliki masyarakat Jakarta, tetapi lambat laun merambah hingga ke daerah-daerah lain di Indonesia. Di beberapa kota besar Indonesia sudah terlihat kecenderungan peningkatan permintaan akan buah naga seperti Surabaya, Denpasar, dan Semarang (Kristanto, 2008).

Buah naga sekarang mulai tersedia di toko buah dan pasar swalayan dan sejumlah perkebunan melirik komoditas ini karena budidayanya mudah dan prospek ke depan cerah dibanding buah lainnya. Saat ini Thailand dan Vietnam merupakan pemasok buah terbesar dunia, tetapi permintaan yang dapat dipenuhi masih kurang dari 50 persen. Pasar lokal saat ini dibanjiri produk ekspor berdasarkan catatan dari eksportir buah di Indonesia, buah naga ini masuk ke tanah air mencapai antara 200-
400 ton/tahun asal Thailand dan Vietnam. Tingginya permintaan buah naga ini di sebabkan oleh promosi yang menyebutnya sebagai buah meja (sangat menarik dan menggiurkan bila di sajikan di meja makan) berkhasiat mujarab untuk berbagai penyakit dan bermanfaat sebagai bahan baku di bidang industri pengolahan makanan, minuman, kosmetik serta produk kesehatan (Anonim, 2008 ).

Usahatani buah naga di Kabupaten Pamekasan masih tergolong baru dan daerah pengembangannya juga masih terbatas. Pada saat ini, wilayah pengembangan usahatani buah naga berada di Desa Blumbungan. Namun, karena masih baru berjalan, sehingga diperlukan analisis untuk pengembangannya. Oleh karena itu, maka kami tertarik untuk meneliti faktorfaktor internal dan eksternal dalam usahatani buah naga.

\section{METODE PENELITIAN}

\section{A. Lokasi dan Waktu Penelitian}

Penelitian ini dilakukan di Desa Blumbungan, Kecamatan Larangan, Kabupaten Pamekasan, Madura, Jawa Timur. Pemilihan lokasi tersebut dilakukan secara sengaja (purposive) dengan pertimbangan bahwa Desa Blumbungan merupakan daerah pengembangan buah naga organik di Kabupaten Pamekasan.

\section{B. Jenis Data}

Data yang digunakan adalah data primer dan data sekunder. Data primer 
merupakan data yang diperoleh langsung dari lapangan yaitu dengan melakukan wawancara langsung dengan pihak - pihak terkait dalam hal ini Dinas Pertanian, Kantor Informasi Penyuluhan Pertanian dan Kehutanan, Petani Organik, Petani Semi Organik, Petani Konvensional, Tokoh Masyarakat Setempat, Penggagas Pertanian Organik, Konsumen/ Pelaku Pasar Produk Organik.

Data sekunder diperoleh dengan mengumpulkan sumber tertulis atau dokumen dari Kantor Desa, Kecamatan, Dinas Pertanian, dan dari berbagai buku pustaka yang ada kaitan dengan penelitian ini.

\section{Populasi, Sampel dan Instrumen Penelitian}

Populasi dalam penelitian ini adalah pihak-pihak yang terkait dengan pengembangan pertanian organik. Penentuan jumlah sampel tidak dibatasi tetapi melihat perkembangan informasi yang diperoleh peneliti melalui angket (kuesioner), wawancara dan observasi yang dilakukan. Adapun sampel yang diwawancarai adalah :

1. Petani yang melaksanakan budidaya buah naga secara semi organik dan masih memberi toleransi terhadap penggunaan pupuk / pestisida sintetis.

2. Petani konvensional yang dalam proses budidaya masih mengandalkan bibit unggul, pupuk dan pestisida sintetis.
3. Tokoh penggagas / perintis pertanian organik

4. Tokoh lokal setempat

5. Pejabat pemerintah dari Dinas Pertanian, Kantor Informasi Penyuluhan Pertanian dan Kehutanan, dan Kecamatan.

6. Konsumen / pelaku pasar buah naga organik Blumbungan

Tabel 2. Nara Sumber Penggalian Informasi

\begin{tabular}{c|l|c}
\hline No. & \multicolumn{1}{|c}{ Narasumber } & $\begin{array}{l}\text { Jumlah } \\
\text { (orang) }\end{array}$ \\
\hline \multicolumn{3}{c}{ Pemerintah } \\
\hline 1. & Kepala Desa Blumbungan & 1 \\
\hline 2. & Camat Larangan & 1 \\
\hline 3. & $\begin{array}{l}\text { Dinas Pertanian Kabupaten } \\
\text { Pamekasan }\end{array}$ & 3 \\
\hline 4. & $\begin{array}{l}\text { Kantor Informasi } \\
\text { Penyuluhan Pertanian dan } \\
\text { Kehutanan }\end{array}$ & 2 \\
\hline 5. & $\begin{array}{l}\text { Penggagas Masyarakat } \\
\text { Pertanian Organik }\end{array}$ & 2 \\
\hline 6. & Tokoh Masyarakat & 8 \\
\hline 7. & $\begin{array}{l}\text { Pengurus Kelompok Tani } \\
\text { Desa Blumbungan (semi } \\
\text { organik) }\end{array}$ & 3 \\
\hline 8. & $\begin{array}{l}\text { Anggota Kelompok Tani } \\
\text { Desa Blumbungan (semi } \\
\text { organik) }\end{array}$ & 20 \\
\hline 9. & Petani Konvensional pasar \\
\hline 10. & $\begin{array}{l}\text { Konsumen/pelaku } \\
\text { buah naga organik }\end{array}$ \\
\hline
\end{tabular}

Kemudian instrumen penelitian yang digunakan adalah daftar pertanyaan (questionaire). Kuesioner diberikan kepada anggota kelompok tani organik untuk mengetahui tanggapan mereka mengenai pertanian organik. Kuesioner mengandung pertanyaan berkaitan dengan identifikasi terhadap faktor-faktor eksternal dan faktorfaktor internal. 


\section{Analisis Data}

Analisis Data yang digunakan untuk mengetahui tujuan yang ingin dicapai adalah :

\section{Matriks Internal Factor Evaluation}

(IFE) merupakan sebuah alat formulasi strategi yang digunakan untuk meringkas dan mengevaluasi kekuatan dan kelemahan utama dalam area fungsional bisnis, dan juga memberikan dasar untuk mengidentifikasi dan mengevaluasi hubungan antara area-area tersebut (David, 2006).

2. atriks Eksternal Factor Evaluation (EFE) digunakan untuk mengetahui faktorfaktor eksternal perusahaan berkaitan dengan peluang dan ancaman yang dianggap penting. Data eksternal dikumpulkan untuk menganalisis hal-hal menyangkut persoalan ekonomi, sosial, budaya, demografi, lingkungan, politik, pemerintahan, hukum, teknologi, dan persaingan (David, 2006).

Adapun tahap-tahap dalam dalam mengidentifikasi faktor-faktor lingkungan eksternal dalam matriks IFE adalah sebagai berikut:

1. Tuliskan faktor internal utama seperti diidentifikasi dalam proses audit internal.

2. Berikan bobot yang berkisar dari 0,0 (tidak penting) hingga 1,0 (sangat penting) untuk masing-masing faktor. Bobot yang diberikan kepada masing-masing faktor mengindikasikan tingkat penting relatif dari faktor terhadap keberhasilan perusahaan dalam industri. Jumlah seluruh bobot harus sebesar 1,0.

3. Berikan peringkat 1 sampai 4 untuk masing-masing faktor untuk mengindikasikan apakah faktor tersebut menunjukkan kelemahan mayor (peringkat $=1$ ), atau kelemahan minor (peringkat $=2$ ), kekuatan minor (peringkat $=3$ ), atau kekuatan mayor (peringkat $=$ 4). Perhatikan bahwa kekuatan harus mendapatkan peringkat 3 atau 4, dan kelemahan harus mendapat peringkat 1 atau 2. Jadi, peringkat adalah berdasarkan perusahaan, sedangkan bobot adalah berdasarkan industri.

4. Kalikan masing-masing bobot faktor dengan peringkat untuk menentukan rata-rata tertimbang untuk masingmasing variabel.

5. Jumlahkan rata-rata tertimbang untuk masing-masing variabel untuk menentukan total rata-rata tertimbang untuk organisasi. Nilai rata-rata adalah 2,5. Total rata-rata tertimbang di bawah 2,5 menggambarkan organisasi yang lemah secara internal, sementara total nilai di atas 2,5 mengindikasikan posisi internal yang kuat.

Tahap-tahap dalam mengidentifikasi faktor-faktor lingkungan eksternal dalam matriks EFE adalah sebagai berikut: 
1. Buat daftar faktor eksternal yang diidentifikasi dalam proses audit eksternal.

2. Berikan bobot yang berkisar dari 0,0 (tidak penting) hingga 1,0 (sangat penting) untuk masing-masing faktor. Bobot mengindikasikan tingkat penting relatif dari faktor terhadap keberhasilan perusahaan dalam industri. Jumlah seluruh bobot harus sebesar 1,0.

3. Berikan peringkat 1 sampai 4 untuk masing-masing faktor eksternal kunci tentang seberapa efektif strategi perusahaan saat ini dalam merespon faktor tersebut, dimana $4=$ respon perusahaan superior, $3=$ respon perusahaan di atas rata-rata, $2=$ respon perusahaan rata-rata, $1=$ respon perusahaan jelek. Peringkat didasari pada efektivitas strategi perusahaan, sedangkan bobot didasarkan pada industri.

4. Kalikan masing-masing bobot faktor dengan peringkatnya untuk menentukan nilai tertimbang.

5. Jumlahkan nilai tertimbang dari masingmasing variabel untuk menentukan total nilai tertimbang bagi organisasi. Nilai nilai tertimbang tertinggi adalah 4,0 dan nilai tertimbang terendah adalah 1,0. Total nilai tertimbang rata-rata adalah 2,5. Total nilai tertimbang sebesar 4,0 mengindikasikan bahwa organisasi merespon dengan sangat baik terhadap peluang dan ancaman yang ada dalam industrinya. Dengan kata lain, strategi perusahaan secara efektif mengambil keuntungan dari peluang yang ada saat ini dan meminimalkan efek yang mungkin muncul dari ancaman eksternal. Total nilai 1,0 mengindikasikan bahwa strategis perusahaan tidak memanfaatkan peluang atau tidak menghindari ancaman eksternal.

\section{HASIL DAN PEMBAHASAN}

\section{A. Analisis Lingkungan Internal}

Analisis lingkungan internal merupakan proses identifikasi terhadap faktor-faktor kekuatan dan kelemahan dari usahatani buah naga. Lingkungan internal dari usahatani buah naga dapat dianalisis dengan menggunakan analisis pendekatan fungsional, yaitu analisis yang dilakukan pada masingmasing fungsi dalam usahatani buah naga dengan menganalisis aspek pemasaran, produksi, sumber daya manusia, kondisi keuangan, kegiatan penelitian dan pengembangan serta sistem informasi manajemen dari suatu perusahaan.

Analisis lingkungan internal dalam usahatani buah naga meliputi kekuatan dan kelemahan dari usahatani buah naga organik. Hal ini dapat dilihat pada Tabel 3. 


\section{B. Analisis Lingkungan Eksternal}

Analisis lingkungan eksternal usahatani buah naga mengidentifikasi peluang dan ancaman yang meliputi faktorfaktor aspek politik, aspek ekonomi, aspek sosial, aspek budaya, aspek demografi, aspek lingkungan, aspek teknologi dan aspek persaingan.

Analisis lingkungan eksternal dalam usahatani buah naga meliputi peluang dan ancaman dari usahatani buah naga organik. Hal ini dapat dilihat pada Tabel 4.

\section{Analisis Matriks IFE}

Matriks IFE digunakan untuk mengetahui seberapa besar pengaruh dari faktor-faktor internal usahatani buah naga. Nilai total yang dibobot pada matriks ini merupakan hasil penjumlahan total dari perkalian bobot dan rating masing-masing faktor strategis internal usahatani buah naga. Perhitungan yang lebih rinci dapat dilihat pada Tabel 5 .
Tabel 3. Kekuatan dan Kelemahan Usahatani Buah Naga Organik

\begin{tabular}{|c|c|c|}
\hline $\begin{array}{c}\text { Faktor } \\
\text { Internal }\end{array}$ & Kekuatan & Kelemahan \\
\hline Pemasaran & $\begin{array}{l}\text { - Mutu buah yang } \\
\text { baik dari hasil } \\
\text { produksi. } \\
\text { - Sudah memiliki } \\
\text { pasar tetap. }\end{array}$ & $\begin{array}{l}\text { - Belummemiliki } \\
\text { sertifikasi, } \\
\text { kemasan dan } \\
\text { merek sendiri. }\end{array}$ \\
\hline $\begin{array}{l}\text { Produksi } \\
\text { Operasi }\end{array}$ & $\begin{array}{l}\text { - Iklim dan } \\
\text { kondisi tanah } \\
\text { yang cocok dan } \\
\text { baik dengan } \\
\text { tanaman organik. } \\
\text { - Kemudahan } \\
\text { terhadap akses } \\
\text { input produksi } \\
\text { seperti pupuk } \\
\text { dan obat-obatan } \\
\text { organik }\end{array}$ & $\begin{array}{l}\text { - Produktivitas hasil } \\
\text { produksi } \\
\text { masih rendah. } \\
\text { - Teknologi produksi } \\
\text { belum } \\
\text { menggunakan } \\
\text { screen house. } \\
\text { - Belum } \\
\text { diterapkannya } \\
\text { sortasi dan grading }\end{array}$ \\
\hline SDM & - & $\begin{array}{l}\text { - Sistem organisasi } \\
\text { dan koordinasi } \\
\text { kelompok taimasih } \\
\text { belum terstruktur } \\
\text { dengan baik. } \\
\text { - Kemampuan petani } \\
\text { untuk mengarsip } \\
\text { data produksi dan } \\
\text { keuangan belum } \\
\text { dengan rapi dan } \\
\text { tertulis. } \\
\text { mnya lembaga } \\
\text { penelitian khusus } \\
\text { buah naga }\end{array}$ \\
\hline Keuangan & - & $\begin{array}{l}\text { - Keterbatasan modal } \\
\text { petani untuk } \\
\text { mengembangkan } \\
\text { pertanian organik. }\end{array}$ \\
\hline Litbang & 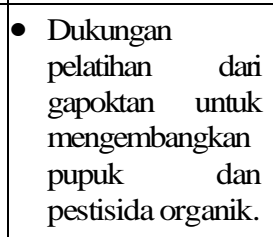 & \\
\hline SIM & - & 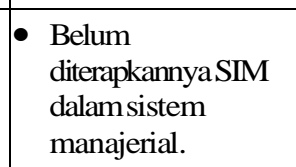 \\
\hline
\end{tabular}


Tabel 4. Peluang dan Ancaman Usahatani Buah Naga Organik

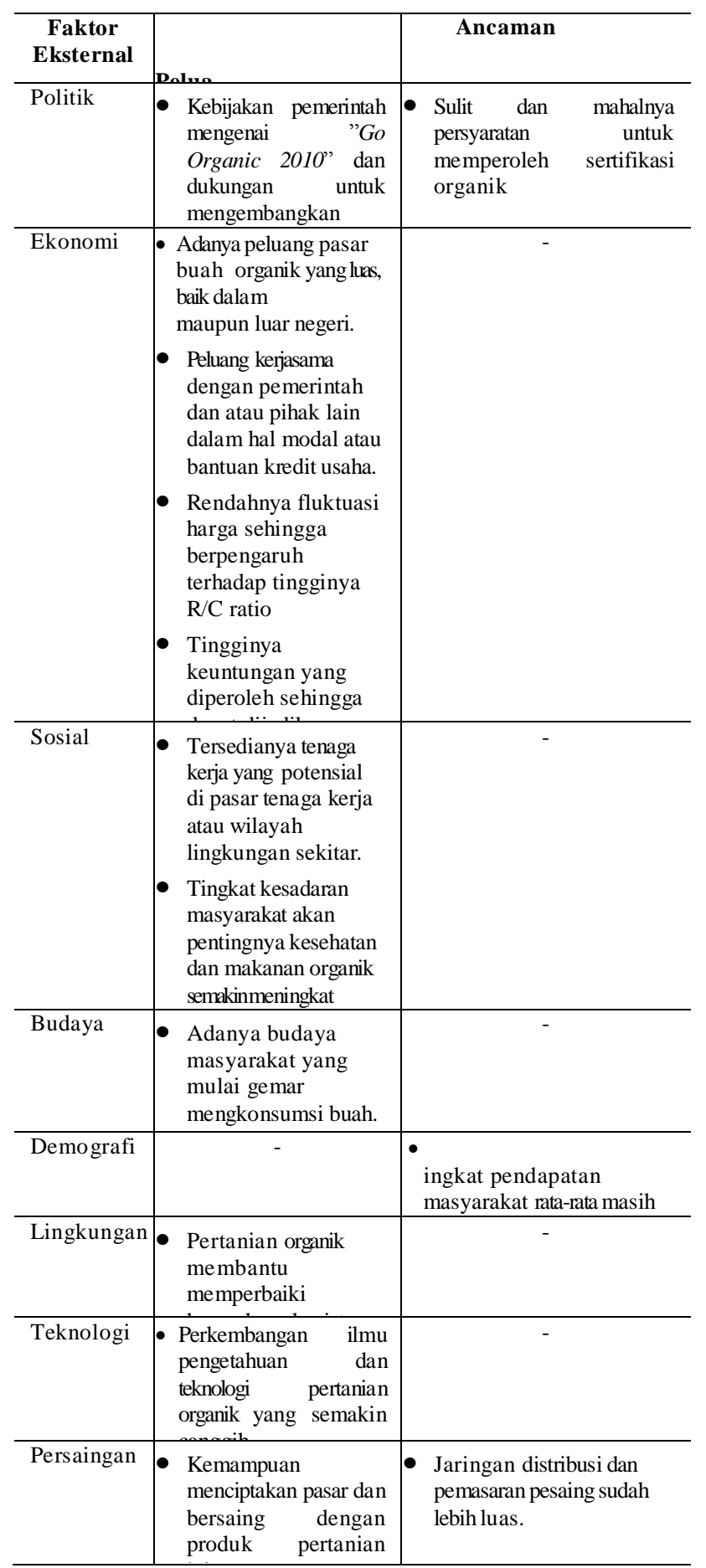

Tabel 5. Hasil Analisis Matriks IFE

\begin{tabular}{c|c|c|c|c}
\hline No & Faktor Internal & $\begin{array}{c}\text { Bobot } \\
\text { (a) }\end{array}$ & $\begin{array}{c}\text { Rating } \\
\text { (b) }\end{array}$ & $\begin{array}{c}\text { Skor } \\
(\mathbf{c}=\mathbf{a x b})\end{array}$ \\
\hline
\end{tabular}

\section{Kekuatan}

\begin{tabular}{c|l|c|c|c}
\hline 1. & $\begin{array}{l}\text { Mutu buah naga yang baik dari } \\
\text { hasil produksi. }\end{array}$ & 0,078 & 3,8 & 0,296 \\
\hline 2. & Sudah memiliki pasar tetap. & 0,090 & 3,8 & $\mathbf{0 , 3 4 2}$ \\
\hline 3. & $\begin{array}{l}\text { Iklim dan kondisi tanah yang } \\
\text { cocok dan baik dengan } \\
\text { tanaman organik. }\end{array}$ & 0,076 & 3,8 & 0,288 \\
\hline 4. & $\begin{array}{l}\text { Kemudahan terhadap akses } \\
\text { input produksi seperti pupuk } \\
\text { dan obat-obatan organik }\end{array}$ & 0,069 & 3,8 & 0,262 \\
\hline 5. & $\begin{array}{l}\text { Dukungan pelatihan dari } \\
\text { Gapoktan untuk } \\
\text { mengembangkan pupuk dan }\end{array}$ & 0,070 & 3,0 & 0,210 \\
\hline
\end{tabular}

\begin{tabular}{|c|c|c|c|c|}
\hline \multicolumn{5}{|c|}{ Kelemahan } \\
\hline 1. & $\begin{array}{l}\text { Belum memiliki sertifikasi } \\
\text { organik, kemasan dan label }\end{array}$ & 0,078 & 1,0 & 0,078 \\
\hline 2. & $\begin{array}{l}\text { Produktivitas hasil produksi } \\
\text { masih rendah. }\end{array}$ & 0,075 & 1,7 & 0,127 \\
\hline 3. & $\begin{array}{l}\text { Teknologi produksi belum } \\
\text { menggunakan screen house. }\end{array}$ & 0,066 & 1,4 & 0,092 \\
\hline 4. & $\begin{array}{l}\text { Belum diterapkannya sortasi dan } \\
\text { grading }\end{array}$ & 0,074 & 1,5 & 0,111 \\
\hline 5. & $\begin{array}{l}\text { Sistem organisasi dan } \\
\text { koordinasi kelompok tani } \\
\text { belum terstruktur dengan baik. }\end{array}$ & 0,069 & 1,8 & 0,124 \\
\hline 6. & $\begin{array}{l}\text { Kemampuan petani untuk } \\
\text { mengarsip data produksi dan } \\
\text { keuangan belum terstruktur } \\
\text { dengan rapi dan tertulis. }\end{array}$ & 0,078 & 1,5 & 0,117 \\
\hline 7. & $\begin{array}{l}\text { Minimnya lembaga penelitian } \\
\text { khusus buah naga }\end{array}$ & 0,058 & 1,2 & 0,070 \\
\hline 8. & $\begin{array}{l}\text { Keterbatasan modal petani untuk } \\
\text { mengembangkan pertanian } \\
\text { oroanik }\end{array}$ & 0,074 & 1,3 & 0,096 \\
\hline \multirow[t]{2}{*}{9.} & $\begin{array}{l}\text { Belum diterapkannya SIM dalam } \\
\text { sistem manajerial. }\end{array}$ & 0,045 & 1,0 & $\mathbf{0 , 0 4 5}$ \\
\hline & Total Skor matriks IFE & 1,000 & & 2,258 \\
\hline
\end{tabular}

Berdasarkan hasil perhitungan

pada tabel matriks IFE, diperoleh bahwa

total nilai skor terbobot sebesar 2,258.

Dari total skor terbobot tersebut dapat

disimpulkan bahwa usahatani buah naga

memiliki posisi internal yang lemah karena

berada di bawah nilai 2,50. Hal ini 
menunjukkan bahwa usahatani buah naga belum mampu dalam memanfaatkan kekuatan yang dimiliki dan mampu mengatasi kelemahan yang ada. Kekuatan utama usahatani buah naga adalah sudah memiliki pasar tetap, dengan skor sebesar 0,342 . Walaupun dalam hal ini, pasar tetap buah naga organik adalah pasar tradisional. Sedangkan kelemahan utama usahatani buah naga yaitu belum diterapkannya SIM dalam sistem manajerial dengan skor sebesar 0,045 .

\section{Analisis Matriks EFE}

Matriks EFE digunakan untuk mengetahui seberapa besar pengaruh dari faktor-faktor eksternal usahatani buah naga. Nilai total yang dibobot pada matriks ini merupakan hasil penjumlahan total dari perkalian bobot dan rating masing-masing faktor strategis eksternal usahatani buah naga. Perhitungan yang lebih rinci dapat dilihat pada Tabel 6 .

Berdasarkan hasil perhitungan pada tabel matriks EFE, diperoleh bahwa total nilai skor terbobot sebesar 2,974. Hal ini menunjukkan bahwa usahatani buah naga sudah relatif kuat dalam memanfaatkan peluang untuk mengatasi ancaman. Peluang utama usahatani buah naga adalah kebijakan pemerintah mengenai "Go Organic 2010" dan dukungan untuk mengembangkan usahatani, dengan skor sebesar 0,252. Sedangkan ancaman utama usahatani buah naga yaitu jaringan distribusi dan pemasaran pesaing sudah lebih luas, dengan skor sebesar 0,250.

Tabel 6. Hasil Analisis Matriks EFE

\begin{tabular}{|c|c|c|c|c|}
\hline No & Faktor Eksternal & $\begin{array}{c}\text { Bobot } \\
\text { (a) }\end{array}$ & $\begin{array}{l}\text { Rating } \\
\text { (b) }\end{array}$ & $\begin{array}{c}\text { Skor } \\
(\mathbf{c}=\mathbf{a x b})\end{array}$ \\
\hline \multicolumn{5}{|c|}{ Peluang } \\
\hline 1. & $\begin{array}{l}\text { Kebijakan pemerintah } \\
\text { mengenai 'GoOrganic } 2010 \text { ' dan } \\
\text { dukungan untukmengembangkan } \\
\text { pertanian organik. }\end{array}$ & 0,084 & 3,0 & 0,252 \\
\hline 2. & $\begin{array}{l}\text { Adanya peluang pasar buah } \\
\text { organik yang luas, baik dalam } \\
\text { maupun luar negeri. }\end{array}$ & 0,073 & 2,7 & 0,197 \\
\hline 3. & $\begin{array}{l}\text { Peluang kerjasama dan } \\
\text { bermitra dengan pemerintah } \\
\text { dan atau pihak lain dalam hal } \\
\text { modal atau bantuan kredit } \\
\text { usaha. }\end{array}$ & 0,071 & 3,2 & 0,227 \\
\hline 4. & $\begin{array}{l}\text { Rendahnya fluktuasi harga } \\
\text { sehingga berpengaruh terhadap } \\
\text { tingginya R/C ratio }\end{array}$ & 0,069 & 2,8 & 0,193 \\
\hline 5. & \begin{tabular}{|lcr} 
Tingginya & keuntungan & yang \\
diperoleh & sehingga & dapat \\
dijadikan & sebagai & usahatani \\
alternatif pengganti tembakau
\end{tabular} & 0,071 & 3,0 & 0,213 \\
\hline 6. & $\begin{array}{l}\text { Tersedianya tenaga kerja } \\
\text { yang potensial di pasar tenaga } \\
\text { kerja atau wilayah lingkungan } \\
\text { sekitar. }\end{array}$ & 0,074 & 2,8 & 0,207 \\
\hline 7. & $\begin{array}{lr}\text { Tingkat } & \text { kesadaran } \\
\text { masyarakat akan } & \text { pentingnya } \\
\text { kesehatan dan } & \text { makanan } \\
\text { organik semakin } & \text { meningkat } \\
\text { tiap tahunnya. } & \end{array}$ & 0,080 & 3,0 & 0,240 \\
\hline 8. & $\begin{array}{l}\text { Pertanian organic membantu } \\
\text { memperbaiki kerusakan } \\
\text { ekosistem. }\end{array}$ & 0,064 & 3,2 & 0,237 \\
\hline 9. & $\begin{array}{l}\text { Perkembangan ilmu } \\
\text { pengetahuan dan teknologi } \\
\text { pertanian organik yang } \\
\text { semakin canggih. }\end{array}$ & 0,068 & 3,5 & 0,238 \\
\hline$\overline{10 .}$ & $\begin{array}{l}\text { Adanya budaya masyarakat } \\
\text { mengkonsumsi buah. }\end{array}$ & 0,056 & 2,8 & 0,157 \\
\hline$\overline{11 .}$ & $\begin{array}{l}\text { Kemampuanmenciptakan pasar dan } \\
\text { bersaing dengan produk } \\
\text { pertanian lainnva. }\end{array}$ & 0,053 & 2,5 & 0,132 \\
\hline \multicolumn{5}{|c|}{ Ancaman } \\
\hline 1. & $\begin{array}{l}\text { Sulit dan mahalnya persyaratan } \\
\text { sertifikasi organik. }\end{array}$ & 0,068 & 3,2 & 0,218 \\
\hline 2. & $\begin{array}{l}\text { Tingkat pendapatan } \\
\text { masyarakat rata-rata masih } \\
\text { rendah. }\end{array}$ & 0,076 & 2,8 & 0,213 \\
\hline \multirow[t]{2}{*}{3.} & $\begin{array}{l}\text { Jaringan distribusi dan } \\
\text { pemasaran pesaing sudah } \\
\text { lebih luas. }\end{array}$ & 0,083 & 3,0 & 0,250 \\
\hline & Total Skor matriks EFE & 1,000 & & 2,974 \\
\hline
\end{tabular}




\section{KESIMPULAN}

\section{A. Kesimpulan}

Adapun kesimpulan dari penelitian diatas adalah sebagai berikut :

1. Berdasarkan hasil perhitungan pada tabel matriks IFE (Internal Factor Evalution), diperoleh bahwa total nilai skor terbobot sebesar 2,258. Dari total skor terbobot tersebut dapat disimpulkan bahwa usahatani buah naga memiliki posisi internal yang lemah karena berada di bawah nilai 2,50. Hal ini menunjukkan bahwa usahatani buah naga belum mampu dalam memanfaatkan kekuatan yang dimiliki dan mampu mengatasi kelemahan yang ada. Kekuatan utama usahatani buah naga adalah sudah memiliki pasar tetap, dengan skor sebesar 0,342. Walaupun dalam hal ini, pasar tetap buah naga organik adalah pasar tradisional. Sedangkan kelemahan utama usahatani buah naga yaitu belum diterapkannya SIM dalam sistem manajerial dengan skor sebesar 0,045.

2. Sedangkan hasil perhitungan pada tabel matriks EFE (Eksternal Factor Evalution), diperoleh bahwa total nilai skor terbobot sebesar 2,974. Hal ini menunjukkan bahwa usahatani buah naga sudah relatif kuat dalam memanfaatkan peluang untuk mengatasi ancaman. Peluang utama usahatani buah naga adalah kebijakan pemerintah mengenai "Go Organic 2010" dan dukungan untuk mengembangkan usahatani, dengan skor sebesar 0,252. Sedangkan ancaman utama usahatani buah naga yaitu jaringan distribusi dan pemasaran pesaing sudah lebih luas, dengan skor sebesar 0,250 .

\section{B. Saran}

1. Usahatani buah naga adalah usahatani layak dilakukan namun hendaknya dikembangkan lagi pada proses pasca panen agar penerimaan petani dapat meningkat.

2. Usahatani buah naga menunjukkan belum mampu dalam memanfaatkan kekuatan yang dimiliki dan mampu mengatasi kelemahan yang ada.kekuatan utama usahatani buah naga adalah sudah memiliki pasar tetap.sedangkan kelemahan utama usahatani buah naga yaitu belum di terapkan SIM dalam sistem manajerial.

3. Kebijakan pemerintah mengenai "Go Organic 2010" harus didukung secara penuh dengan realisasi pelaksanaan untuk mengembangkan usahatani buah naga.

\section{DAFTAR PUSTAKA}

Departemen Pertanian. 2004. Prospek Pertanian Organik. Penelitian dan Pengembangan Departemen Pertanian. http://www.litbang.deptan.go.id/ber ita/one/17 [5 Mei 2010] 
Dinas Pertanian Provinsi Jawa Timur. 2009. Pedoman Pertanian Organik. www.diperta.jatimprov.go.id/ [16 Agustus 2009]

IFOAM, www.ifoam.org

Kadir, Abdul, 2002, Pertanian Organik, Alternatif Pananggulangan Krisis Pertanian Modern Menuju Pertanian yang Berkelanjutan, Makalah Falsafah Sains, http://tumoutou net-702 05123abdul kadir file image002 jpg

Lehman. (1997), Pertanian organik punya prospek cerah. Jagad Majalah Ilmiah Universitas Jenderal Sudirman (Unsoed). Vol (1), no. 1.

Nazir, M. 1989. Metode Penelitian. Ghalia Indonesia, Jakarta.

Pemerintah Kabupaten Pamekasan. 2009. Kecamatan Larangan dalam Angka Tahun 2005. Kabupaten Pamekasan, Pamekasan.

Peraturan Menteri Pertanian Nomor : 02/Pert/HK.060/2/2006 tentang Pupuk Organik dan Pembenah Tanah.

Pidato Pengantar Menteri Pertanian Pada Rapat Kerja dengan Komisi IV DPR RI Tanggal 14 Nopember 2007, http://www.deptan.go.id/

Rangkuti, Freddy. 2001. Analisis SWOT Teknik Membedah Kasus Bisnis. Reorientasi Konsep Perencanaan Strategis untuk Menghadapi Abad 21. PT. Gramedia Pustaka Utama. Jakarta.

Rosalinda, Linda. 2009. Analisis Strategi Pengembangan Usaha Sayuran Organik pada Kelompok Tani Sugih Tani pada Kawasan Agropolitan di Desa Karehkel, Kecamatan Leuwi Liang, Kabupaten Bogor. Skripsi. Departemen Manajemen. Fakultas Ekonomi dan Manajemen. Institut Pertanian Bogor. Bogor.

Saptana, dkk, 2007, Pembangunan Pertanian Berkelanjutan Melalui Kemitraan Usaha, Jurnal Litbang Pertanian, 26(4), 2007, http://www.pustaka.deptan.go.id

Suryana, Achmad, 2005, Pembangunan Pertanian Berkelanjutan Andalan
Pembangunan Nasional, Makalah Seminar Sistem Pertanian Berkelanjutan untuk Mendukung Pembangunan Nasional tanggal 15 Pebruari 2005 di Universitas Sebelas Maret Solo, http://pse.litbang.deptan.go.id

Departemen Pertanian. 2004. Empat Tahun Go Organik 2010. Direktorat Jendral BPPHP. http://agribisnis.deptan.go.id [3 Maret 2010]

Sutanto, Rachman, 2002, Pertanian Organik Menuju Pertanian Alternatif dan Berkelanjutan, Penerbit Kanisius, Yogyakarta. 